\title{
DETERMINANTS FOR IMPROVING THE FINANCIAL SITUATION OF SMALL AND MEDIUM-SIZED COMPANIES - IN THE OPINION OF ENTREPRENEURS
}

\author{
MAŁGORZATA PORADA-ROCHOŃ, ${ }^{1}$ JUSTYNA FRANC-DĄBROWSKA ${ }^{2}$
}

\author{
1 University of Szczecin, Faculty of Management and Economics of Services, POLAND \\ e-mail: malgorzata.rochon@wp.pl \\ ${ }^{2}$ Warsaw University of Life Sciences - SGGW, Faculty of Economic Sciences, POLAND \\ e-mail: justyna_franc_dabrowska@sggw.pl
}

RECEIVED
ACCEPTED
JEL
CLASSIFICATION
KEYWORDS

ABSTRACT
18 January 2018

2 September 2018

G3

small and medium-sized companies, financial crisis, financial condition, financial distress

The dynamics of changes taking place in the environment as well as its variability and complexity create new research perspective. On the one hand, such character of the environment favours the development of companies, and on the other, it creates difficult conditions for conducting business activities and determines a number of threats. Nevertheless, business managers are always on the look for solutions and opportunities that would allow them to achieve higher efficiency of operations. The aim of the research was to identify determinants among which the management of small and medium-sized companies sees the possibilities of improving financial situation. The following research hypothesis was verified: along with the progressing process of globalization of the economy, the determinants of improvement of financial situation of the distorted and undistorted companies are diversified. The research was carried out using the cross-section microdata presented in questionnaires. The survey database contains 100 observations. Respondents were asked about what creates an opportunity to improve the financial condition of companies after the crisis of 2008 . The conducted research allows the conclusion that, regardless of financial condition of small and medium-sized companies, the basic prerequisites for their functioning and improvement of the financial situation are economic development and legislation. These two determinants of improvement of financial situation prevailed in the opinions of the surveyed company managers, regardless of the method of classification of entities. Therefore, it can be concluded that the conducted research proved the regularity known from the literature to be true, and that the research hypothesis was confirmed. 


\section{Introduction}

The dynamics of changes taking place in the environment as well as its variability and complexity create new research perspective. On the one hand, such character of the environment favours the development of companies, and on the other, it creates difficult conditions for conducting business activities and determines a number of threats. Nevertheless, business managers are always on the look for solutions and opportunities that would allow them to achieve higher efficiency of operations.

The aim of this research was to identify variables among which the managers of small and medium-sized companies look for opportunities to improve financial situation.

\section{Financial distress of small and medium-sized companies in the light of national and international research}

On the one hand, macroeconomic factors such as turbulent environment, phases of business cycles, economic shocks and balance disturbed on a global scale determine the operation of SMEs, which, in consequence, affects their financial condition. On the other hand, the performance of business entities is affected by a number of processes and phenomena of microeconomics nature. This, in turn, may cause negative consequences in the form of financial distress, crises, insolvency or bankruptcies of companies.

Financial distress precedes the occurrence of a crisis, whereas in the case of insolvency, it may occur either prior, or take place simultaneously. Financial distress is defined in the literature in various ways, depending on the level of details covered in the research and perspective for investigating such disorders. Nevertheless, financial distresses of companies should be identified with different degrees of deterioration of their financial condition. Porada-Rochon defines financial distress based on the studied literature as a stage in the complex and dynamic deterioration process, which is the result of the impact of a significant external determinant causing a significant deterioration of the financial management, and thus requiring companies to consciously choose the configuration of financial decisions in the adjustment model (Porada-Rochon, 2013, pp. 75-76). The author classifies financial distress in the fields of diagnostics and decisions. In the scope of diagnostics, there can be distinguished: lack of ability to meet liabilities, excessive debt ratio, negative financial results, or bankruptcy and its probability. In the case of decisions there can be indicated: carrying out the adjustment process (restructuring) and obtaining external financing (Franc-Dąbrowska, Porada-Rochoń, Zioło, Babczuk, 2015, pp. 14-15).

Although the occurrence of financial distress and crisis is a common phenomenon, the research results presented by Dębicka suggest that the majority of companies are prepared for potential crisis situation in their current operations. Moreover, the research shows that small companies are more often prepared for such situation - in comparison with medium-sized companies. When asked about the applied warning tools, respondents (53.6\%) indicated forecasting of financial liquidity (Dębicka, 2015, pp. 544-45).

Nevertheless, an important element in the identification of financial distress is skilful selection of signals of the crisis, both those of a financial and non-financial nature, as pointed out by Gorczyńska and her team. The authors emphasize the significance of the concept of the non-compliance gap by pointing to the reasons and the effects of discrepancies between the actual and presented information regarding the financial standing of a company (Gorczyńska, Wieczorek-Kosmala, Znaniecka, 2011, p. 9).

One of the key determinants of the occurrence of financial distress of companies, and thus bankruptcy/ insolvency, is excessive debt ratio. At the same time, it needs to be noted that the structure of SMEs differs 
from large companies as it is dominated by liabilities. On the other hand, Mikołajczyk indicates that micro, small and medium-sized companies display limited internal financing possibilities, and thus limited access to external financing constitutes a key barrier to development of such entities. This barrier stems from the fact that financial institutions have limited trust, especially towards micro and small-sized companies, which in the initial stage do not demonstrate creditworthiness. Moreover, the business activities carried out by micro and small-sized companies entail greater operational risk. One of the more frequently mentioned examples is the creative sector, which due to its specificity and individuality is difficult to be measured financially ex ante, which, consequently, causes problems in accessing external financing (Mikołajczyk, 2007, p. 26).

According to the research results presented by Rogowski and Jankowska (2014, p. 113), the most common financial reasons for bankruptcy include the increase in liabilities, including overdue ones, negative financial results and loss of financial liquidity. The results of Szczerbak's research (Rogowski, 2015, p. 163), similarly to the prior ones, indicate high indebtedness as one of the main reasons for bankruptcy of companies. The research results presented by Pawlonka (2016, p. 136) indicated a strong positive statistical dependence between symptoms of bankruptcy costs and debt level (ex post), and therefore, excessive indebtedness leads to an increase in the probability of bankruptcy costs.

In general, the impact of the global crisis on the financial condition of company was negative, which is confirmed by the results of Porada-Rochon's research. The author investigated the influence of crisis on the financial condition of those companies whose financial condition ex ante was worse (financial distress), and proved that the influence was significant and exposed the instability of financial condition as well as low capability for operating during crisis (Porada-Rochoń, 2013, pp. 148-149).

Campello with his team conducted research on financial constraints of companies during crisis. They recognized ensuring liquidity as the basic problem faced by companies operating in unstable environment (Campello, Graham, Harvey, 2010, p. 470). On the other hand, the results presented by Dos Santos with team after conducting research among 6,184 companies in Portugal in the years 2008-2012 indicate that companies show a high level of debt, mainly short-term liabilities (Lourenço, Oliveira, p. 625). Claessens with his team presented seemingly interesting results (Claessens, Tong, Wei, 2012, p. 375). The authors examined 7,722 non-financial companies in 42 countries and proved that the crisis had a greater negative impact on entities with greater sensitivity to changes in business cycle and in trade, especially in countries more open to trade.

Kahle and Stulz examined indebted companies dependent on banks. The obtained results suggest that the dependent companies do not decrease capital expenditure more than companies that are not dependent on banks in the first year of the crisis or in two quarters after the bankruptcy of Lehman Brothers. Moreover, the companies dependent on banks accumulate funds during crisis, contrary to no indebted companies (Kahle, Stulz, 2012, p. 270).

The research results concerning Irish small and medium-sized companies provide evidence that companies with a high level of financial liquidity before the crisis increased the level of trade credit granted to counterparts, and then improved their financial results in comparison to companies that, ex ante, had a low level of financial liquidity. Furthermore, the level of trade credit taken by financially distressed companies increased (Garcia-Appendini, Montoriol-Garriga, 2013, p. 272).

Lawless with his team conducted research among Irish companies. Its aim was to verify if outstanding liabilities incurred by small and medium-sized companies reduce current expenditure after the financial crisis. The authors proved that a higher level of debt (measured as the debt/turnover ratio) has a significant negative 
impact on all measures/indicators of the company's results, in particular investments, employment and financial distress indicators, whereas these results/effects are most visible in the case of sectors and companies dependent most heavily on domestic demand, which decreased after the crisis. Furthermore, the effects are the strongest in the case of companies that were mature before the crisis (Lawless, O'Connell, O'Toole, 2015, p. 45).

Campa and Mamacho-Minano (2015, p. 222) prove that medium-sized companies with higher financial distress level show signs of yield management by manipulating transactions instead of accounting accruals.

As the presented results show, the crisis had, to varying degrees, a negative impact on the financial condition of SMEs in the world, with the degree and scope of this deterioration being different and dependent on a number of external and internal determinants. A decade after the crisis, business environment seems to be more stable, which is reflected in satisfying financial results of Polish small and medium-sized companies.

The report of the NBP indicates that the liquidity of companies remained at a high, safe level in the third quarter of 2016. Debt under loans and credits increased by approx. 5.6\% YOY, however, the increase was lower than in the previous quarter, which resulted from a decrease in debt under credits and/or short-term loans. Debt under credits and/or long-term loans continues to show an upward trend (Narodowy Bank Polski, 2016, pp. 75-76).

According to the research results published in the PEKAO Bank Report on the situation of micro and small sized companies in 2017 (2018, pp. 75-76), in general, the financial condition of companies from the SME sector in 2016 and 2017 was satisfactory. However, in 2017, there could be observed real deterioration, which was reflected by a lower percentage of profitable companies. Furthermore, the data prepared by Euler Hermes shows that, in June 2018 in Poland, 101 cases of company insolvency were identified, as compared to 71 in June 2017 (increase by $48 \%$ ) (Euler Hermes, 2018).

The events of the recent decade, especially between the years 2007/2008, exacerbated the difficulties in the scope of fulfilling company's goals, as well as affected the occurrence of a number of dysfunctions, including those in financial economy, and increased the risk of financial distress.

\section{The aim, methodology and scope of the research}

The research was conducted using study material in the form of cross-sectional micro-data obtained from surveys. Survey database includes 100 observations. The research was carried out in April 2015 among 100 small and medium-sized companies, as well as 6 joint-stock companies. The surveyed companies were located in Zachodniopomorskie voivodeship. A questionnaire was used. The respondents were asked 15 questions (6 were included in particulars to determine the respondent profile, while 9 were used to diagnose the phenomenon of the disorder).

Bearing in mind the problem of financial distress of small and medium-sized companies, the respondents were asked, as part of the conducted research, about opportunities to improve the financial condition of companies after the 2008 crisis. The obtained results were divided into three categories. In the first case, the answers were evaluated using Likert scale (where rating 1 was assigned to those factors which, in the opinion of entrepreneurs, have the slightest impact on the improvement of the financial situation, and 5 was chosen for the most important ones). Then, the opinions of small and medium-sized company directors were broken down by the legal forms of the entities. Subsequently, the companies were allocated to one of two groups - a group which achieved positive financial result, and a group which suffered a decline. The results were presented in a tabular form. 
The following research hypothesis was verified: after the economic turmoil caused by the crisis in 2008, entrepreneurs expect stabilization under applicable law and economic development.

\section{Research results}

Table 1 presents results of the research during which entrepreneurs were asked about factors that create an opportunity to improve the financial situation of their companies. At the same time, the opinions of entrepreneurs were divided into groups using Likert five-point scale, where groups 1 and 2 included determinants of minor importance for the improvement of the financial situation, while groups 4 and 5 presented factors with the greatest influence on the company financial situation. It was found that entrepreneurs deemed the chance to improve financial situation to be low, despite using EU funds coming from the new 2014-2020 perspective, and the implementation of investments as part of cooperation with other entities. In turn, entrepreneurs saw the biggest chance to improve financial situation in the possibility to amend the restructuring and rehabilitation law. At the same time, they also indicated benefits from investments carried out in the previous period. Another important factor for them was the improvement in economic growth forecasts after 2014. The most important factors in improving the financial situation for all managers of the SMEs included improvement of economic growth forecasts, i.e. looking for a chance in good times for the entire economy, as well as amendments to the restructuring and rehabilitation law.

Taking account of the opinions presented by the directors of small and medium-sized companies, it should be stated that after the crisis of 2008 , factors important to the improvement of financial situation included overall economic development and legislation that would enable efficient implementation of recovery processes, if necessary.

Table 1. What creates an opportunity to improve the financial situation of companies, including the division of companies into 5 groups

\begin{tabular}{|c|c|c|c|c|c|}
\hline \multirow{2}{*}{ Answer } & \multirow{2}{*}{$\begin{array}{l}\text { Number } \\
\text { of answers }\end{array}$} & \multicolumn{3}{|c|}{ Percentage of answers } & \multirow{2}{*}{$\begin{array}{l}\text { Weighted arithmetic } \\
\text { mean of answers }\end{array}$} \\
\hline & & 1 and 2 & 3 & 4 and 5 & \\
\hline P19_1. EU financial funds from the new 2014-2020 perspective & 100 & 46 & 26 & 28 & 2.90 \\
\hline \multicolumn{6}{|l|}{ P19_2. Investment carried out until 2013, which will generate operating } \\
\hline revenues & 100 & 28 & 36 & 36 & 3.14 \\
\hline P19_3. Improved forecasts regarding economic growth after 2014 & 100 & 16 & 48 & 36 & 3.28 \\
\hline \multicolumn{5}{|l|}{ P19_4. Proposed amendments to the restructuring and rehabilitation law } & 3.22 \\
\hline \multicolumn{6}{|l|}{ P19_5. Implementation of investments as part of cooperation with other } \\
\hline entities & 100 & 46 & 30 & 24 & 2.86 \\
\hline P19_6. Clusters & 100 & 43 & 24 & 33 & 2.86 \\
\hline P19_7. Other answers & 100 & 43 & 24 & 33 & 2.86 \\
\hline
\end{tabular}

1-5 Groups - agreed grading of possibilities to improve the financial situation in accordance with Likert five-point scale (1 - minimum, 5 - maximum).

Source: own research.

Table 2 presents distribution of answers regarding factors conditioning the improvement of the financial situation of SMEs, while taking into account their legal forms. The representatives of sole proprietorship, when asked about the most important factors, most often indicated the effects of previous investments, improvement in the country's economic situation, amendments to the restructuring and rehabilitation law and cooperation within 
clusters. On the other hand, the representatives of civil law companies seek improvement of financial situation in the financial funds from the new perspective, and more importantly, amendments to the regulations. The same was true for the opinions of representatives of limited liability companies (the effects of already implemented investments were also important for this group).

Therefore, it can be concluded that there could be observed significant differ-ences in determinants conditioning the financial situation of small and medium-sized companies, depending on their legal form.

Table 2. Distribution of answers, including legal forms of companies (\%)

\begin{tabular}{|c|c|c|c|}
\hline \multirow[b]{3}{*}{ P19_1. EU financial funds from the new $2014-2020$ perspective } & SP & Civil law company & Limited liability company \\
\hline & $48(=100)$ & $25(=100)$ & $21(=100)$ \\
\hline & 27.1 & 40.0 & 23.8 \\
\hline P19_2. Investment carried out until 2013, which will generate operating revenues & 33.3 & 28.0 & 52.4 \\
\hline P19_3. Improved forecasts regarding economic growth after 2014 & 43.8 & 28.0 & 28.6 \\
\hline $\begin{array}{l}\text { P19_4. Proposed amendments to the restructuring and rehabilitation law } \\
\text { for entrepreneurs }\end{array}$ & 39.6 & 52.0 & 57.1 \\
\hline P19_5. Implementation of investments as part of cooperation with other entities & 25.0 & 16.0 & 33.3 \\
\hline P19_6. Clusters & 37.5 & 28.0 & 28.6 \\
\hline P19_7. Other answers & 31.3 & 32.0 & 38.1 \\
\hline
\end{tabular}

$\mathrm{SP}$ - sole proprietorship.

Source: own research.

The results of the research in Table 3 appear to be interesting. They were presented with the division of companies into a group that generated profits, and the one that incurred a loss. Regardless of whether the companies were in a better (profit) or worse (loss) financial situation, the same factors determining the improvement of their condition were chosen. The most popular included the proposition to amend the restructuring and rehabilitation law. Therefore, it is confirmed that legal measures in which companies operate are an important factor for entrepreneurs. The entrepreneurs who suffered losses pointed to the possibility of improving financial condition as a result of completed investments, as well as connecting improvement of efficiency with general economic

Table 3. Distribution of answers, including legal forms of companies (\%)

\begin{tabular}{|c|c|c|c|c|c|c|}
\hline \multirow{3}{*}{ Answer } & net profit & \multicolumn{2}{|l|}{ Profit } & \multicolumn{3}{|c|}{ Loss } \\
\hline & 2009 & 2010 & 2011 & 2009 & 2010 & 2011 \\
\hline & $51(=100)$ & $60(=100)$ & $59(=100)$ & $49(=100)$ & $40(=100)$ & $41(=100)$ \\
\hline P19_1. EU financial funds from the new 2014-2020 perspective & 25.5 & 25.0 & 23.7 & 30.6 & 32.5 & 34.1 \\
\hline $\begin{array}{l}\text { P19_2. Investment carried out until 2013, which will generate } \\
\text { operating revenues }\end{array}$ & 33.3 & 33.3 & 30.5 & 38.8 & 40.0 & 43.9 \\
\hline P19_3. Improved forecasts economic growth after 2014 & 37.3 & 31.7 & 35.6 & 34.7 & 42.5 & 36.6 \\
\hline $\begin{array}{l}\text { P19_4. Proposed amendments to the restructuring and } \\
\text { rehabilitation law for entrepreneurs }\end{array}$ & 43.1 & 40.0 & 44.1 & 49.0 & 55.0 & 48.8 \\
\hline $\begin{array}{l}\text { P19_5. Implementation of investments as part of cooperation } \\
\text { with other entities }\end{array}$ & 9.8 & 16.7 & 18.6 & 38.8 & 35.0 & 31.7 \\
\hline P19_6. Clusters & 31.4 & 35.0 & 33.9 & 34.7 & 30.0 & 31.7 \\
\hline P19_7. Other answers & 37.3 & 40.0 & 40.7 & 28.6 & 22.5 & 22.0 \\
\hline
\end{tabular}

Source: own research. 
development. Financially sound entrepreneurs considered cooperation with other entities and joint implementation of investments less important, which in turn was avital determinant for the entities at a loss.

\section{Conclusions}

Small and medium-sized companies constitute a key group of business entities that determine economic development. At the same time, the state of the economy and globalization processes affect entities from that sector. The occurring dependencies are of a bilateral nature. The research shows that there is a group of determinants that is important for the management of small and medium-sized companies in the process of improving their financial situation.

It was found that, in the opinion of managers of SMEs, key factors used to improve the financial situations constitute the overall economic development and legislation that would enable efficient implementation of repair processes, if necessary. It has likewise been agreed that there were observed significant differences in determinants conditioning the financial situation of small and medium-sized companies, depending on their legal form, and thus different proposals for development support should be proposed to entities functioning as sole proprietorship, civil law company, and limited liability company. It seems interesting that the entrepreneurs who suffered losses looked for improvement of financial condition in cooperation with other entities, while the management of companies that made profit focused on other determinants.

The conducted research allows the conclusion that, regardless of financial condition of small and mediumsized companies, the basic prerequisites for their functioning and improvement of the financial situation are economic development and legislation. These two determinants of improvement of financial situation prevailed in the opinions of the surveyed company managers, regardless of the method of classification of entities. Therefore, it can be concluded that the conducted research proved the regularity known from the literature to be true, and that the research hypothesis was confirmed.

\section{Acknowledgments}

The project was financed from the funds of the National Science Center granted on the basis of decision number DEC-2011/03/B/HS4/05503.

\section{References}

Bank PeKao (2018). Raport o sytuacji mikro, małych firm w 2017 roku. Warszawa. Retrieved from: https://www.pekao.com.pl/ binsource/f/00/Raport_2018_pol.pdf.

Campa, D., Camacho-Minano, M. (2015). The impact of SME" pre bankruptcy financial distress on earnings management tools. International Review of Financial Analysis, 42, 222-234. Retrieved from: https://www.sciencedirect.com/science/article/pii/ S1057521915001313.

Campello, M., Graham, J.R., Harvey C.R. (2010). The real effects of financial constraints: Evidence from a financial crisis. Journal of Financial Economic, 97 (3), 470-487 Retrieved from: https://www.sciencedirect.com/science/article/pii/S0304405X10000413\#!

Claessens, S., Tong, H., Wei, S.J. (2012). From the financial crisis to the real economy: Using firm-level data to identify transmission channels. Journal of International Economics, 88 (2), 375-387. Retrieved from: https://www.sciencedirect.com/science/article/ pii/S0022199612000426 (24.05.2018).

Dębicka, A. (2015). System wczesnego ostrzegania w zarzadzaniu sytuacja kryzysową w małym i średnim przedsiębiorstwie. Zeszyty Naukowe Uniwersytetu Szczecińskiego, 848. Ekonomiczne Problemy Usług, 116, 544-545. 
Euler Hermes (2018). Negatywne perspektywy dla polskiej gospodarki to już rzeczywistość. Informacja prasowa. Retrieved from: http:/l www.eulerhermes.pl/euler-hermes-w-polsce/centrum-prasowe/wiadomosci/Lists/NewsDocuments/EH_niewyplacalnosci_ Ipo\%c5\%82rocze_2018.pdf.

Franc-Dąbrowska, J., Porada-Rochoń, M., Zioło, M., Babczuk, A. (2015). Stabilizowanie finansów podmiotów sektora publicznego i prywatnego w warunkach zaburzeń finansowych. Warszawa: CeDeWu.

Garcia-Appendini, E., Montoriol-Garriga, J. (2013). Firms as liquidity providers: Evidence from the 2007-2008 financial crisis. Journal of Financial Economics, 109 (1), 272-291. Retrieved from: https://www.sciencedirect.com/science/article/pii/ S0304405X13000536.

Gorczyńska, M., Wieczorek-Kosmala, M., Znaniecka, K. (2011). Kryzys przedsiębiorstwa z perspektywy jego sytuacji finansowej. Studia Ekonomiczne. Uniwersytet Ekonomiczny w Katowicach, 77, 9-21.

Kahle, K.M., Stulz, R.M. (2013). Access to capital, investment, and the financial crisis. Journal of Financial Economics, 110 (2), $280-$ 299. Retrieved from: https://www.sciencedirect.com/science/article/pii/S0304405X13000573.

Lawless, M., O'Connell, B., O'Toole, C. (2015). SME recovery following a financial crisis: Does debt overhang matter? Journal of Financial Stability, 19, 45-59. Retrieved from: https://www.sciencedirect.com/science/article/pii/S1572308915000534.

Lourenço, A., José Dos Santos Morão, Oliveira, E.C. (2017). Determinants of debt: Empirical evidence on firm in the district of Santarém in Portugal. Contaduria y Administraction, 62 (2), 625-543. Retrieved from: https://www.sciencedirect.com/science/article/pii/ S0186104217300098.

Mikołajczyk, B. (2007). Infrastruktura finansowa MSP w krajach Unii Europejskiej. Warszawa: Difin.

Pawlonka, T. (2016). Weryfikacja zależności wynikających z wybranych teorii struktury kapitału na przykładzie przedsiębiorstw branży mięsnej w Polsce. Metodyczne studium przypadku. Warszawa: Wydawnictwo SGGW.

Porada-Rochoń, M. (2013). Modele decyzji finansowych w wybranych krajach Europy Środkowo-Wschodniej w warunkach zaburzeń finansowych. Szczecin: PTE.

Rogowski, W., Jankowska, K. (2014). Przyczyny upadłości spółek akcyjnych w Polsce w latach 2008-2012 - analiza zjawiska. Studia i Prace Kolegium Zarządzania i Finansów/ SGH, 140, 89-122.

Rogowski, W. (2015). Przyczyny upadłości polskich przedsiębiorstw - ujęcie empiryczne. Studia i Prace Kolegium Zarzadzania i Finansów/SGH, 144, 161-196.

Narodowy Bank Polski (2016). Sytuacja finansowa sektora przedsiębiorstw w III kw. 2016 r. Retrieved from: https://www.nbp.pl/ publikacje/przedsiebiorstwa/raport_03_2016.pdf.

Cite this article aS: Porada-Rochoń, M., Franc-Dąbrowska, J. (2018). Determinants for improving the financial situation of small and medium-sized companies - in the opinion of entrepreneurs. European Journal of Service Management, 3 (27/2), 355-362. DOI: 10.18276/ ejsm.2018.27/2-43. 